\title{
Synthesis and Biological Evaluation of New Fragments from Kirromycin Antibiotic
}

\author{
P. Tavecchia*, A. Marazzi, C. Dallanoce, A. Trani, I. Ciciliato, \\ P. Ferrari, E. Selva and R. Ciabatti \\ Lepetit Research Center,
} Via R. Lepetit 34, 21040 Gerenzano (VA), Italy

(Received for publication June 26, 1996)

\begin{abstract}
New $N$-acyl derivatives of $1-N$-desmethyl goldinamine were obtained from degradation of kirromycin. Periodate-oxidation of these derivatives provided new aldehydic fragments that were further elaborated. Both $N$-phenyl ureido and $N$-phthalimido derivatives of 1 - $N$-desmethyl goldinamine are able to inhibit bacterial protein synthesis in cell-free assay and are active against whole microorganisms, although with lower potency than kirromycin. The derivatives from the aldehydic fragments are totally inactive.
\end{abstract}

Kirromycin 1 (Fig. 1) is a natural microbial product, produced by fermenting Streptomyces sp. and Actinoplanes sp. strains. Compound $\mathbf{1}$ belongs to the "elfamycin" class of antibiotics. Elfamycins inhibit bacterial protein synthesis by binding elongation factor $\mathrm{Tu}(\mathrm{EF}-\mathrm{Tu})$ to form a non-dissociable ribosome/EF$\mathrm{Tu} /$ antibiotic complex ${ }^{1,2)}$. They are characterized by a restricted spectrum of antibacterial activity. These antibiotics are selectively active against Streptococci, anaerobes and some Gram-negative pathogens such as Neisseria gonorrhoeae and Haemophilus influenzae ${ }^{3,44}$. Membrane permeability is a critical factor in Escherichia coli which is insensitive to $\mathbf{1}$ but has a kirromycin-sensitive EF-Tu ${ }^{5,6)}$. On the contrary, Staphylococcus aureus is insensitive because its EF-Tu is kirromycin-resistant ${ }^{7)}$. Extensive and elegant chemical degradation work was performed on kirromycin and related microbial products to elucidate the structure ${ }^{8)}$. Information on structureactivity relationships has been derived from degradation studies, from the comparison of the antimicrobial activity of different elfamycins produced by microorganisms and from derivatives prepared from aurodox and kirromycin ${ }^{9,10)}$. In particular, an aldehydic fragment obtained from periodate oxidation of kirromycin was claimed to possess all the effects of the natural antibiotic in cellfree experiments although endowed with lower potency than kirromycin ${ }^{11}$. This aldehydic fragment lacks the pyridone-trienic-tetrahydro furane moiety suggesting that this part of the molecule is not strictly essential for the binding and for the biological activity. Indeed, NMR studies showed that the pyridone ring of kirromycin is not intimately involved in the binding to $\mathrm{EF}-\mathrm{Tu}^{12)}$. Additional indications derive from naturally occuring elfamycins. The polyketide core structure of kirromycin is conserved in aurodox, heneicomycin, SB22484 and efrotomycin. Structures of antibiotics factumycin, A73A, UK69753 and kirrothricin appear to result from the opening of the tetrahydrofuran ring. Antibiotics L-681,217, phenelfamycins, ganefromycin (LL-E19020) and A83016F lack the pyridone moiety. All these antibiotics show comparable antimicrobial profile and mode of action. These facts suggest that the pyridone moiety and the tetrahydrofuran ring are not essential for the activity. We prepared degradation products of kirromycin and some of their derivatives and evaluated their biological activities. The aim was to acquire information about the minimal structural requirement of elfamycins essential to maintain their biological activity.

\section{Chemistry}

We used for our chemical work kirromycin 1 that was obtained by fermenting a kirromycin producer microorganism Actinoplanes sp. A8924 ${ }^{13)}$. It was reported ${ }^{8)}$ that kirromycin 4- $O$-methyl ether 2 underwent a selective

Fig. 1. Molecular structure of kirromycin (1) and its 4-O-methyl derivative (2).

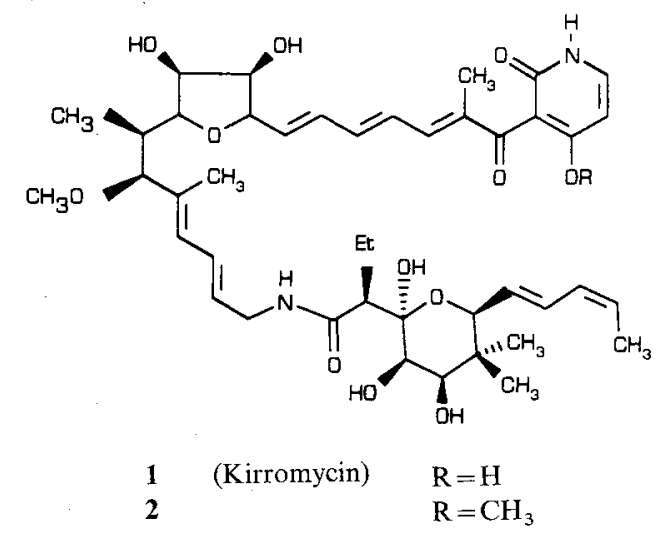


cleavage of the amide bond when exposed to acetic acid at room temperature for 4 days, or when heated on the steam bath for 30 minutes. This reaction provided 4$O$-methyl $\mathrm{N}$-desmethyl goldinamine 3 as its acetic acid salt (Scheme 1) with a yield of about $20 \%$ for the two chemical steps (protection/hydrolysis). We studied the amidic cleavage of the unprotected natural compound 1 to generate $N$-desmethyl goldinamine 4 (Scheme 1). The best results were achieved when 1 reacted in acetic acid at room temperature for 114 hours or in dioxane at $35^{\circ} \mathrm{C}$ for 22 hours in presence of formic acid $99 \%$. In both cases compound $\mathbf{4}$ was recovered in good yield and acceptable purity (75\% HPLC) after a simple "work up". Prolonged reaction time or higher temperatures gave lower yields or more side products. Reaction of $\mathbf{1}$ with either potassium hydrogen sulfate, ammonium chloride, citrate buffer, or camphorsulfonic acid in dioxane, or aqueous dioxane at $25 \sim 60^{\circ} \mathrm{C}$ afforded low yields $(0 \sim 26 \%)$ of 4 . The ${ }^{1} \mathrm{H}$ and ${ }^{13} \mathrm{C}$ NMR spectra of compound $\mathbf{4}$ formate salt are in agreement with the previously reported data ${ }^{14)}$ (Table 1 ).

The amino group of $\mathbf{4}$ was then derivatized. Acetylation of 4 (pyridine/acetic anhydride/4-dimethylamino pyridine) followed by overnight treatment with metha-

Scheme 1.

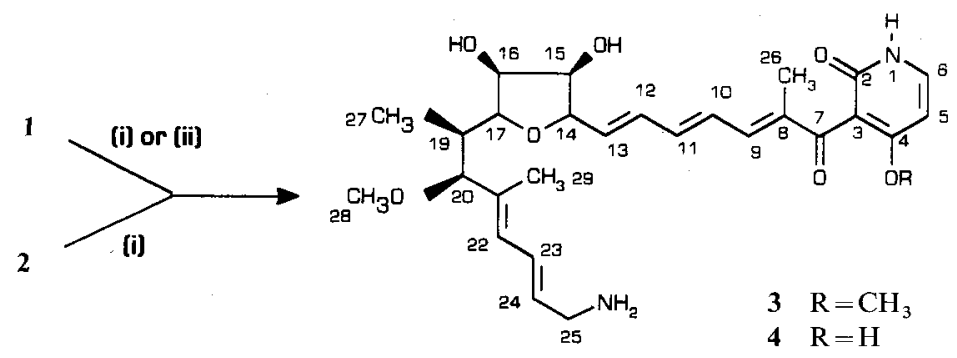

(i) Acetic acid, R.T.; (ii) dioxane-HCOOH $99 \%, 35^{\circ} \mathrm{C}$.

Table $1 .{ }^{1} \mathrm{H}$ and ${ }^{13} \mathrm{C}$ NMR data of compound 4 .

\begin{tabular}{|c|c|c|c|c|c|}
\hline Position & Coupling & ${ }^{1} \mathrm{H} \mathrm{NMR}^{\mathrm{a}, \mathrm{b}}$ & $J(\mathrm{~Hz})$ & ${ }^{13} \mathrm{C} N \mathrm{NMR}^{\mathrm{a}}$ & Long range \\
\hline 1 & $\mathrm{HCOO}^{-}$ & $8.3 \mathrm{~s}$ & & 163.9 & \\
\hline 2 & $\mathrm{C}=\mathrm{O}$ & & & 165.0 & $\mathrm{H}-6$ \\
\hline 3 & $\mathrm{C}$ & & & 111.5 & $\mathrm{H}-5$ \\
\hline 4 & $\mathrm{C}$ & & & 162.0 & $\mathrm{H}-6$ \\
\hline 5 & $\mathrm{CH}$ & $5.95 \mathrm{~d}$ & 7.2 & 99.2 & $\mathrm{H}-6$ \\
\hline 6 & $\mathrm{CH}$ & $7.23 \mathrm{~d}$ & 7.2 & 136.2 & $\mathrm{H}-5$ \\
\hline 7 & $\mathrm{C}=\mathrm{O}$ & & & 196.0 & $\mathrm{H}-26, \mathrm{H}-9$ \\
\hline 8 & $\mathrm{C}$ & & & 136.4 & $\mathrm{H}-26, \mathrm{H}-10$ \\
\hline 9 & $=\mathrm{CH}$ & $6.83 \mathrm{~d}$ & 10.1 & 140.0 & H-26, H-10 \\
\hline 10 & $=\mathrm{CH}$ & $6.62 \mathrm{dd}$ & $15.2 \sim 10.1$ & 128.5 & $\mathrm{H}-12$ \\
\hline 11 & $=\mathrm{CH}$ & $6.59 \mathrm{dd}$ & $15.2 \sim 9.7$ & 139.9 & H-13, H-10, H-9 \\
\hline 12 & $=\mathrm{CH}$ & $6.34 \mathrm{dd}$ & $15.2 \sim 9.7$ & 131.6 & $\mathrm{H}-14, \mathrm{H}-10$ \\
\hline 13 & $=\mathrm{CH}$ & $5.96 \mathrm{~m}$ & & 136.5 & H-15 \\
\hline 14 & $\mathrm{CH}$ & $4.16 \mathrm{dd}$ & $7.6 \sim 6.1$ & 79.8 & $\mathrm{H}-16, \mathrm{H}-13, \mathrm{H}-12$ \\
\hline 15 & $\mathrm{CH}$ & $4.12 \mathrm{dd}$ & $6.1 \sim 4.6$ & 73.2 & H-13 \\
\hline 16 & $\mathrm{CH}$ & $4.08 \mathrm{dd}$ & $6.1 \sim 4.6$ & 72.6 & $\mathrm{H}-19, \mathrm{H}-17, \mathrm{H}-14$ \\
\hline 17 & $\mathrm{CH}$ & $3.80 \mathrm{dd}$ & $5.1 \sim 4.6$ & 80.3 & H-27, H-20, H-16, H-15 \\
\hline 19 & $\mathrm{CH}$ & $2.06 \mathrm{ddq}$ & $7.2 \sim 9.3 \sim 4.6$ & 35.0 & $\mathrm{H}-27, \mathrm{H}-20$ \\
\hline 20 & $\mathrm{CH}$ & $3.35 \mathrm{~d}$ & 9.3 & 89.3 & $\mathrm{H}-29, \mathrm{H}-28, \mathrm{H}-27, \mathrm{H}-22$ \\
\hline 21 & $\mathrm{C}$ & & & 137.9 & $\mathrm{H}-29, \mathrm{H}-23$ \\
\hline 22 & $=\mathrm{CH}$ & $6.03 \mathrm{~d}$ & 11.0 & 128.1 & H-29, H-24, H-20 \\
\hline 23 & $=\mathrm{CH}$ & $6.64 \mathrm{dd}$ & $15.1 \sim 11.0$ & 130.6 & H-25 \\
\hline 24 & $=\mathrm{CH}$ & $5.71 \mathrm{dt}$ & $15.1 \sim 6.4$ & 125.5 & $\mathrm{H}-25, \mathrm{H}-22$ \\
\hline 25 & $\mathrm{CH}_{2}$ & $3.50 \mathrm{~m}$ & & 40.6 & $\mathrm{H}-24, \mathrm{H}-23$ \\
\hline 26 & $\mathrm{CH}_{3}$ & $1.86 \mathrm{~s}$ & & 11.5 & \\
\hline 27 & $\mathrm{CH}_{3}$ & $0.74 \mathrm{~d}$ & 7.2 & 12.6 & \\
\hline 28 & $\mathrm{CH}_{3}$ & $3.06 \mathrm{~s}$ & & 55.8 & \\
\hline 29 & $\mathrm{CH}_{3}$ & $1.64 \mathrm{~s}$ & & 11.3 & \\
\hline
\end{tabular}

Chemical shifts (ppm) in DMSO- $d_{6}$.

b The $\mathrm{OH}, \mathrm{NH}_{2}$ peaks and the pyridone $\mathrm{NH}$ peak are not observed. 
nolic-ammonia solution gave the $N$-acetyl derivative 5 in poor yield.

The reaction of compound $\mathbf{4}$ with phenyl isocyanate in dimethylformamide gave in good yield the $N$ phenylureido derivative 6. Attempts to obtain $N$ phthalimido derivative $\mathbf{8}$ according to the classical methodology ${ }^{15)}$ (phthalic anhydride, $\mathrm{CHCl}_{3}, 70^{\circ} \mathrm{C}$ ) yielded a complex reaction mixture. Instead, compound 8 was obtained under mild conditions from $\mathbf{4}$ by using $N$-tert-butoxycarbonyl phthalimide 7 in the presence of triethylamine at room temperature. Reagent 7 was prepared from phthalimide, di-tert-butyldicarbonate and 4-dimethylaminopyridine as a catalyst in dioxane.

The periodate-oxidation of compound $\mathbf{6}$ was, at first, performed following the procedure reported for goldinamine acetate salt ${ }^{8}$. A mixture of products was obtained containing mainly the compound cleaved at the tetrahydrofuran glycol moiety as indicated by mass spectroscopy analyses. Additional evidence that the periodateoxidative step did not occur according to Hesse-Mix ${ }^{16)}$ criteria, was the lack of the transient red-wine color, a marker for the over oxidation after the initial glycol cleavage. It appeared that the $\mathrm{N}$-protected goldinamine behaved differently from the goldinamine acetate salt. Considering that the main difference was the "ionization status" of the amino group, we were led to speculate that goldinamine acetate salt could have behaved as a buffer in the reaction mixture. Indeed, when compound 6 was submitted to the periodate-oxidation in the presence of

Scheme 2

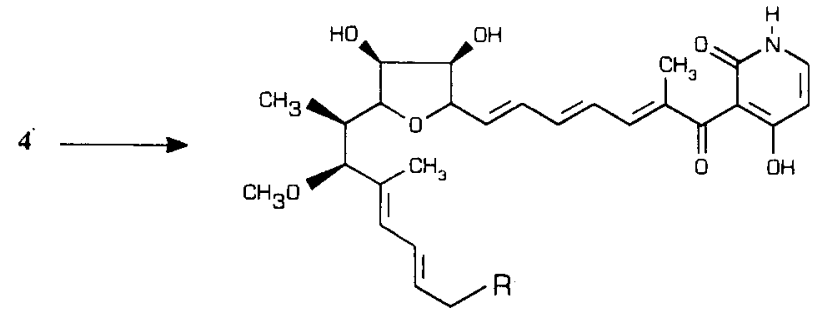

5

$$
\mathrm{R}=-\mathrm{NHCOCH}_{3}
$$<smiles>CNC(=O)Nc1ccccc1</smiles>

8

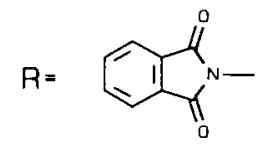

5, Pyridine-acetic anhydride, DMAP (cat.) then $\mathrm{NH}_{3} /$ ethanol; 6, DMF-dioxane, $\mathrm{NEt}_{3}$, phenyl isocyanate; 8 , DMFdioxane, $\mathrm{NEt}_{3}, N$-tert-butoxycarbonylphthalimide (7). ammonium acetate, an immediate a transient red-wine color appeared and the aldehydic fragment 9 was isolated. The periodate-oxidation of 6 worked also in the presence of ammonium formate and acetic acid. On the contrary, the periodate-oxidation in the presence of potassium acetate, or phosphate buffer $(\mathrm{pH}=7)$ did not work. This suggests that the $\mathrm{pH}$ of the reaction mixture is critical in forming the enol necessary for further oxidation. The $\mathrm{N}$-phtalimido aldehyde $\mathbf{1 0}$ was obtained from $\mathbf{8}$ under the same conditions. Both compounds 9 and $\mathbf{1 0}$ were smoothly transformed into their 2,4-dinitrophenylhydrazones 11 and 12. The reduction of compound 9 with sodium borohydride and the reaction with 4-methyl-1aminopiperazine gave the corresponding alcohol 13 and hydrazone 14 respectively in good yields. Two carbon homologation of aldehydes 9 and $\mathbf{1 0}$ by a Wittig-Horner reaction with triethyl phosphonacetate produced the corresponding $\alpha-\beta$ unsaturated esters 15 and 17 , respectively. The two new olefinic hydrogens at $7.02 \mathrm{ppm}$ (dd) and $5.84 \mathrm{ppm}$ (d) show a coupling constant of $15 \sim 16 \mathrm{~Hz}$ indicating an $E$ (trans) configuration. Compound 15 was then treated with $\mathrm{NaOH} 1 \mathrm{~N}$ in dioxane

Scheme 3 .
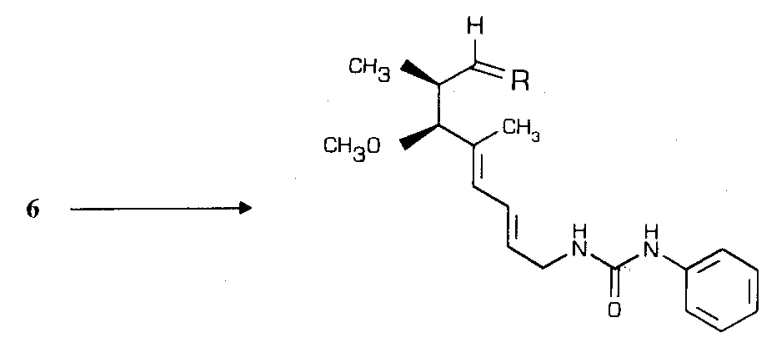

9

$$
R=0
$$

11
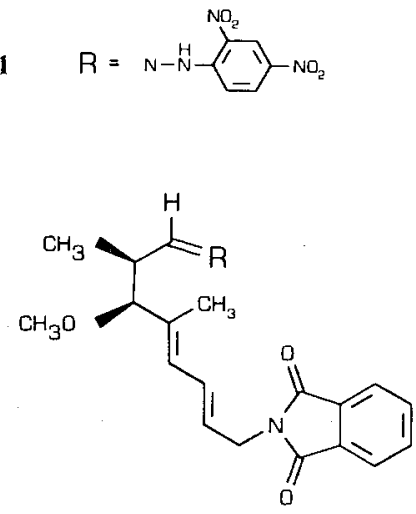

10

$\mathrm{R}=\mathrm{O}$

12

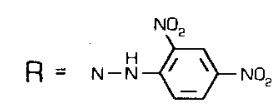

9 and 10, Dioxane-MeOH-water, ammonium acetate sodium metaperiodate; 11 and 12, 2,4-dinitrophenylhydrazine, EtOH 
Scheme 4 .

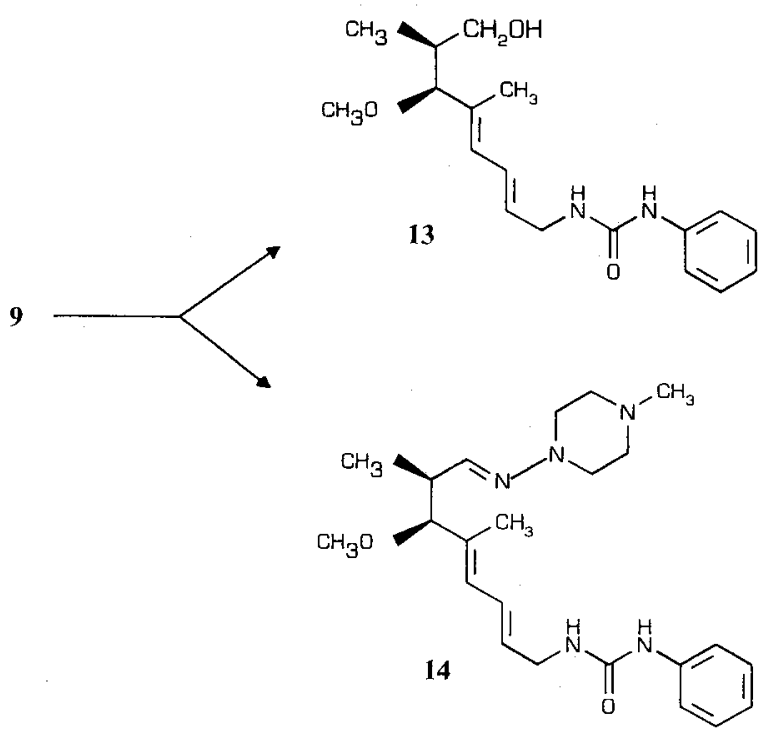

13, Sodium borohydride, EtOH; 14, THF, 4-methyl-1aminopiperazine.

9<smiles>CO[C@H](C)[C@@H](C)/C=C/C(=O)O</smiles>

$15 \quad \mathrm{R}=\mathrm{E} t$

$16 \quad \mathrm{R}=\mathrm{H}$ to provide the corresponding free carboxylic acid 16.

\section{Biological Evaluation}

Activities of the kirromycin derivatives against microorganisms and on poly(U)-directed protein synthesis are reported in Tables 2 and 3, respectively.

The $N$-desmethyl goldinamine $\mathbf{4}$ and its acetyl derivative 5 were completely inactive in both systems. These results are in line with literature data ${ }^{9}$. Compounds 6 and 8 , however, showed significant activity against test microorganisms, although lower than that of 1. These compounds also showed detectable crossresistance with 1 on Enterococcus hirae ATCC 8043 mutant strain resistant to kirromycin ${ }^{17)}$ (Table 3). This suggests that these compounds maintain the EF-Tu molecular target. In cell-free experiments, compounds 6 and $\mathbf{8}$ inhibited bacterial protein synthesis with a potency about ten and one hundred time less than that of 1 . This is likely to be due to a decreased affinity of compounds 6 and 8 for EF-Tu. It was reported ${ }^{18)}$ that kirromycin altered the rate of EF-Tu cleavage by trypsin. Fig. 2 shows that compound $\mathbf{6}$ did not posses the kirromycin effects on the kinetics of proteolytic cleavage. A low affinity for EF-Tu is indeed consistent with this behaviour.

Compounds 6 and 8 were further cleaved at the tetrahydrofuran ring yielding the corresponding aldehydes that were then transformed. The aldehydic derivatives 13, 14, 15, 16 and 17 showed no biological activity. Only compound $\mathbf{1 1}$ was marginally active on the cell free system of protein synthesis.

15, THF, NaH 60\%, triethyl phosphonacetate; 16, dioxane, $\mathrm{NaOH} 1 \mathrm{~N}$.

Scheme 5.

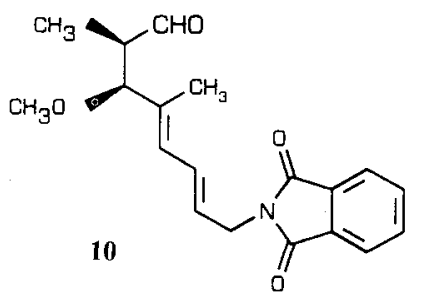

(i)

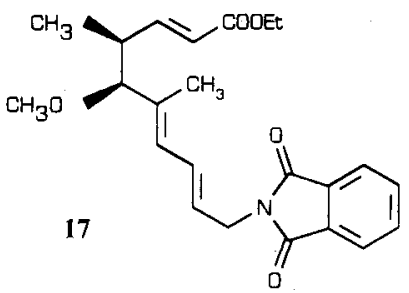

(i) THF, NaH $60 \%$, triethyl phosphonacetate.

Table 2. Cell free protein synthesis of kirromycin and related derivatives.

\begin{tabular}{|c|c|c|c|c|c|c|c|c|c|c|c|c|}
\hline Compounds & 1 & 4 & 5 & 6 & 8 & 11 & 12 & 13 & 14 & 15 & 16 & 17 \\
\hline $\mathrm{IC}_{50}(\mu \mathrm{g} / \mathrm{ml})$ & 0.14 & $\gg 125$ & $\gg 125$ & 1.76 & 17 & 117 & $\gg 128$ & $\gg 128$ & $\gg 128$ & $\gg 128$ & $\gg 128$ & $\gg 128$ \\
\hline
\end{tabular}


Table 3. Antibacterial activity (MIC, $\mu \mathrm{g} / \mathrm{ml}$ ) of selected compounds.

\begin{tabular}{|c|c|c|c|c|c|c|c|c|c|c|c|}
\hline Strains & 1 & 4 & 5 & 6 & 8 & 11 & 13 & 14 & 15 & 16 & 17. \\
\hline S. aureus Smith & $>128$ & $>128$ & $>128$ & $>128$ & $>128$ & $>128$ & $>128$ & $>128$ & $>128$ & $>128$ & $>128$ \\
\hline S. pyogenes $\mathrm{C} 203$ & 4 & $>128$ & $>128$ & 64 & $>128$ & $>128$ & $>128$ & $>128$ & $>128$ & $>128$ & $>128$ \\
\hline S. pneumoniae UC41 & 0.25 & $>128$ & $>128$ & 8 & $>128$ & $>128$ & $>128$ & $>128$ & $>128$ & $>128$ & $>128$ \\
\hline E. hirae ATCC 8043 & 1 & $>128$ & $>128$ & 16 & 64 & $>128$ & $>128$ & $>128$ & $>128$ & $>128$ & $>128$ \\
\hline E. hirae ATCC 8043 res. & $>128$ & $>128$ & $>128$ & $>128$ & $>128$ & $>128$ & $>128$ & $>128$ & $>128$ & $>128$ & $>128$ \\
\hline E. faecium NCTC 7171 & 2 & $>128$ & $>128$ & $>128$ & $>128$ & $>128$ & $>128$ & $>128$ & $>128$ & $>128$ & $>128$ \\
\hline N. gonorrhoeae ISM68/126 & 0.06 & $>128$ & $>128$ & 1 & 4 & $>128$ & $>128$ & $>128$ & $>128$ & $>128$ & $>128$ \\
\hline $\begin{array}{l}\text { H. influenzae type B } \\
\text { ATCC } 19418\end{array}$ & 4 & $>128$ & $>128$ & 128 & $>128$ & $>128$ & $>128$ & $>128$ & $>128$ & $>128$ & $>128$ \\
\hline M. catarrhalis ATCC 8176 & 0.06 & $>128$ & $>128$ & 8 & 4 & $>128$ & $>128$ & 64 & 32 & $>128$ & $>128$ \\
\hline E. coli SKF 12140 & $\geq 128$ & $>128$ & $>128$ & $>128$ & $>128$ & $>128$ & $>128$ & $>128$ & $>128$ & $>128$ & $>128$ \\
\hline E. coli $\mathrm{K} 12$ hyperp. & 8 & $>128$ & $>128$ & 128 & 128 & $>128$ & $>128$ & $>128$ & $>128$ & $>128$ & $>128$ \\
\hline
\end{tabular}

Fig. 2. Effect of kirromycin and compound 6 on trypsin cleavage of EF-Tu.

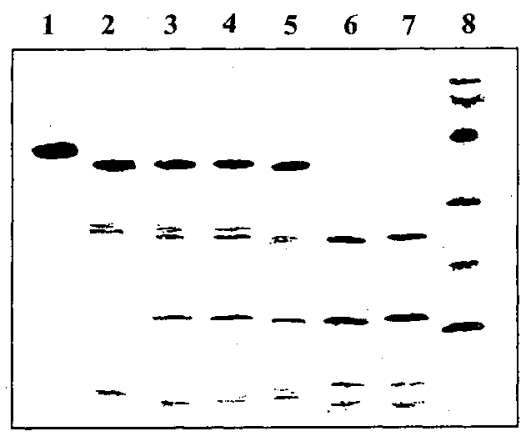

1) EF-Tu undegested; 2) EF-Tu/kirromycin/trypsine (2 minutes); 3) EF-Tu/compound 6/trypsine (2 minutes); 4) EF-Tu/trypsine (2 minutes); 5) EF-Tu/kirromycin/trypsine (30 minutes); 6) EF-Tu/compound 6/trypsine (30 minutes); 7) EF-Tu/trypsine (30 minutes); 8) low molecular weight standard.

\section{Conclusion}

$N$-Acyl derivatives of $\mathbf{4}$ were prepared to evaluate the contribution to the activity of some of these substituents. The $N$-acetyl derivative $\mathbf{5}$ was completely inactive whereas compounds $\mathbf{6}$ and $\mathbf{8}$, bearing an aromatic substituent still maintained some antimicrobial activity. This unexpected result indicates that the pyranosidic moiety (goldinoic acid) present in all the naturally occurring elfamycins can be substituted by other suitable moieties. Additional cleavage at the furane ring of these bioactive derivatives produced microbiologically inactive compounds.

\section{Experimental}

MPs were determined with a Büchi Model 510 capillary apparatus and are uncorrected. The IR absorption spectra were recorded with an I.F.S. 48 Bruker F.T.I.R. spectrophotometer. Optical rotations were measured with a Perkin-Elmer Model 241 polarimeter. All NMR experiments were performed on a Bruker AM 500 or Bruker AMX 600 spectrometer equipped with a X32 computer. The MS spectra were obtained with a triple stage quadrupole spectrometer TSQ 700 Finningan or Perkin-Elmer API PLUS III SCIEX. The elemental analyses were carried out with a Carlo Erba Mod. 1106 equipped with Eager computer. HPLC analysis for compound 4: Hewlett Packard 1090 Liquid Chromatograph equipped with a $3390 \mathrm{~A}$ Hewlett Packard integrator. Detection UV at $254 \mathrm{~nm}$. Column Lichrocart 125-4 (Merck) Lichrospher 100 RP18 (5 $\mu \mathrm{m})$. Mobile phase A: $\mathrm{NaH}_{2} \mathrm{PO}_{4} 0.02 \mathrm{M}$; mobile phase $\mathrm{B}$ : acetonitrile. Flow-rate: $1 \mathrm{ml} /$ minute; gradient profile time (minutes) 0 (B 15\%), 1 (B 15\%), 30 (B 75\%), 32 (B 75\%), 35 (B $15 \%)$. The reactions were monitored by TLC on Silica Gel 60 F254 (Merck) and detected by UV (254 nm).

\section{1- $N$-Desmethylgoldinamine (4)}

Kirromycin (1) (20 g; $25.12 \mathrm{mmol})$ in $200 \mathrm{ml}$ of dioxane and $50 \mathrm{ml}$ of formic acid $99 \%$ was stirred at $35^{\circ} \mathrm{C}$ for 22 hours. After cooling, the reaction mixture was concentrated to half of its volume and then $250 \mathrm{ml}$ of $\mathrm{Et}_{2} \mathrm{O}$ were added. The solvent was decanted and the gummy residue was stirred in $\mathrm{Et}_{2} \mathrm{O}-\mathrm{EtOAc}(1: 1 \mathrm{v} / \mathrm{v})$. The solid material obtained was washed with $\mathrm{Et}_{2} \mathrm{O}$ and dried at room temperature to give $12 \mathrm{~g}$ of 4 formic acid salt $(21.97 \mathrm{mmol}$, yield $87 \%$ ) as a yellow solid that was used without further purification. An analytical sample was obtained from $200 \mathrm{mg}$ by chromatographic purification on silanized silica gel (33 g; Merck-70 $\sim 230$ mesh) eluting with $\mathrm{H}_{2} \mathrm{O}-\mathrm{CH}_{3} \mathrm{CN}$ 9:1 $(300 \mathrm{ml}) ; \mathrm{H}_{2} \mathrm{O}-\mathrm{CH}_{3} \mathrm{CN} 8: 2$ $(200 \mathrm{ml})$ and $\mathrm{H}_{2} \mathrm{O}-\mathrm{CH}_{3} \mathrm{CN} 6: 4(100 \mathrm{ml})$. After evaporation of the acetonitrile and freeze-drying, $60 \mathrm{mg}$ of pure formic acid salt 4 was obtained as a pale yellow amorphous solid: Rt (HPLC) 8.0/8.3 minutes; ${ }^{1} \mathrm{H}$ NMR and ${ }^{13} \mathrm{C}$ see Table 2; IR (Nujol) $\mathrm{cm}^{-1} 1691,1650,1599$; $[\alpha]_{\mathrm{D}}^{25}-37.9^{\circ}(c 0.08, \mathrm{MeOH})$; ESI-MS $m / z 501\left(\mathrm{MH}^{+}\right.$, $55 \%), 484$ (10\%), $445(100 \%), 429(15 \%), 371$ (30\%).

Anal Calcd for $\mathrm{C}_{27} \mathrm{H}_{36} \mathrm{~N}_{2} \mathrm{O}_{7}$ : C 64.8, H 7.2, N 5.6. Found: 


\section{1-N-Desmethyl-25- $N$-acetylgoldinamine (5)}

1-N-Desmethyl goldinamine formate (4) (302 $\mathrm{mg}$, $0.55 \mathrm{mmol}$ ) was dissolved in $5 \mathrm{ml}$ anhydrous pyridine at room temperature and acetic anhydride $(3.8 \mathrm{ml}, 40.2$ mmol) and catalytic amounts of dimethylaminopyridine were added. After stirring for 3 hours, the reaction was diluted with $30 \mathrm{ml}$ of $1 \mathrm{~N} \mathrm{HCl}$ and extracted with $\mathrm{CHCl}_{3}$ $(2 \times 40 \mathrm{ml})$. The organic phase was washed with $50 \mathrm{ml}$ of $1 \mathrm{~N} \mathrm{HCl}$, dried on $\mathrm{Na}_{2} \mathrm{SO}_{4}$ and evaporated. The crude product was treated with $2 \mathrm{ml}$ of $12 \%$ ammonia in methanol at room temperature overnight. The reaction was acidified with $8 \% \mathrm{HCl}$ in $\mathrm{MeOH}$ and then evaporated. The residue was dissolved in water and extracted with $n$-BuOH. The organic phase was evaporated under vacuum to give $290 \mathrm{mg}$ of brown solid material that was purified on silanized silica gel eluting with water, water acetonitrile from $95: 5$ to $75: 25$. The fractions containing the product were collected, the solvent eliminated under vacuum and the resulting solid washed with $\mathrm{Et}_{2} \mathrm{O}$ to obtain pure compound $\mathbf{5}$ (18.3 $\mathrm{mg})$ : Rt (HPLC) 11.4/12.01 minutes, gradient profile as for compound 4; IR (Nujol) $\mathrm{cm}^{-1} 1691,1616,1540,1212 ;[\alpha]_{\mathrm{D}}^{25}-16.98^{\circ}$ (c $0.53, \mathrm{MeOH})$; FAB-MS $m / z 543\left(\mathrm{MH}^{+}, 35 \%\right), 511$ $(70 \%), 262(100 \%) ;{ }^{1} \mathrm{H}$ NMR (DMSO-d 6$) \delta 7.98(1 \mathrm{H}$, brs), 7.17 (1H, brs), $6.79(1 \mathrm{H}, \mathrm{d} 8.3 \mathrm{~Hz}), 6.60(1 \mathrm{H}, \mathrm{m})$, $6.40(2 \mathrm{H}, \mathrm{m}), 5.98(2 \mathrm{H}, \mathrm{m}), 5.66(1 \mathrm{H}, \mathrm{m}), 4.49(2 \mathrm{H}, \mathrm{m})$, $4.40(1 \mathrm{H}, \mathrm{m}), 4.12(1 \mathrm{H}, \mathrm{m}), 4.09(1 \mathrm{H}, \mathrm{m}), 3.74(2 \mathrm{H}, \mathrm{m})$, $3.05(3 \mathrm{H}, \mathrm{s}), 2.06(1 \mathrm{H}, \mathrm{m}), 1.86(3 \mathrm{H}, \mathrm{s}), 1.81(3 \mathrm{H}, \mathrm{s}), 1.76$ $(3 \mathrm{H}, \mathrm{s}), 0.74(3 \mathrm{H}, \mathrm{d} 6.8 \mathrm{~Hz})$.
Anal Calcd for $\mathrm{C}_{29} \mathrm{H}_{38} \mathrm{~N}_{2} \mathrm{O}_{8}$ : Found:
C 64.2, H 7.01, N 5.16 .
C 63.8, H 6.90, N 5.02 .

\section{1- $N$-Desmethyl-25- $N$-phenylureidogoldinamine (6)}

To a solution of compound 4 formic acid salt $(500 \mathrm{mg}$; $0.91 \mathrm{mmol})$ in $3 \mathrm{ml}$ of DMF, triethylamine $(0.32 \mathrm{ml}$; $2.29 \mathrm{mmol})$ and phenyl isocyanate $(99 \mu \mathrm{l} ; 0.91 \mathrm{mmol})$ were added at $0^{\circ} \mathrm{C}$. After stirring at room temperature for 1 hour, the reaction was diluted with ice cold water $(20 \mathrm{ml})$ and acidified with $2.75 \mathrm{ml}$ of $1 \mathrm{~N} \mathrm{HCl}$. The precipitate was filtered, washed with water and then with $\mathrm{Et}_{2} \mathrm{O}$. The crude solid material was purified by flash chromatography $\left(\mathrm{CHCl}_{3}-\mathrm{MeOH} 95: 5\right)$ to give $282 \mathrm{mg}$ of $\mathbf{6}$ $(0.45 \mathrm{mmol}$; yield $50 \%)$ as a yellow solid. An analytical sample was obtained by reversed phase chromatography (water - acetonitrile from $90: 10$ to $70: 30$ ): Rt (HPLC) 15.8 minutes, gradient profile as for compound 4; IR (Nujol) $\mathrm{cm}^{-1} 1691,1650,1597,1549 ;{ }^{1} \mathrm{H} \quad \mathrm{NMR}$ $\left(\mathrm{DMSO}-d_{6}\right) \delta 11.1(1 \mathrm{H}$, br s), $10.9(1 \mathrm{H}, \mathrm{br} \mathrm{s}), 8.42(1 \mathrm{H}$, s), $7.38(2 \mathrm{H}, \mathrm{d} 9.5 \mathrm{~Hz}), 7.28(1 \mathrm{H}, \mathrm{d} 7.1 \mathrm{~Hz}), 7.22(2 \mathrm{H}, \mathrm{t}$ $8.3 \mathrm{~Hz}), 6.88(1 \mathrm{H}, \mathrm{m}), 6.83(1 \mathrm{H}, \mathrm{d} 9.4 \mathrm{~Hz}), 6.63(2 \mathrm{H}, \mathrm{m})$, $6.44(1 \mathrm{H}, \mathrm{dd} 11,14.9 \mathrm{~Hz}), 6.35(1 \mathrm{H}, \mathrm{dd}), 6.25(1 \mathrm{H}, \mathrm{t}$ $5.6 \mathrm{~Hz}), 6.01(2 \mathrm{H}, \mathrm{m}), 5.93(1 \mathrm{H}, \mathrm{d} 7.3 \mathrm{~Hz}), 5.72(1 \mathrm{H}, \mathrm{m})$, $4.47(2 \mathrm{H}, \mathrm{m}), 4.14(2 \mathrm{H}, \mathrm{m}), 4.05(1 \mathrm{H}, \mathrm{m}), 3.77(3 \mathrm{H}, \mathrm{m})$, $3.32(1 \mathrm{H}, \mathrm{d} 9.5 \mathrm{~Hz}), 3.06(3 \mathrm{H}, \mathrm{s}), 2.09(1 \mathrm{H}, \mathrm{m}), 1.87(3 \mathrm{H}$, $\mathrm{s}), 1.61(3 \mathrm{H}, \mathrm{s}), 0.75(3 \mathrm{H}, \mathrm{d} 6.9 \mathrm{~Hz}) ;[\alpha]_{\mathrm{D}}^{25}-39.7^{\circ}(c 0.095$, $\mathrm{MeOH})$; ESI-MS $m / z 620\left(\mathrm{MH}^{+}, 80 \%\right), 331(35 \%), 310$ $(100 \%), 279(38 \%)$. Anal Calcd for $\mathrm{C}_{34} \mathrm{H}_{41} \mathrm{~N}_{3} \mathrm{O}_{8}$ :
Found:

C 65.89, H 6.67, N 6.78 .

C 65.42, H 6.59 , N 6.67 .

$N$-(tert-Butoxycarbonyl)phthalimide (7)

To a suspension of phthalimide $(3 \mathrm{~g} ; 20.4 \mathrm{mmol}), 3 \mathrm{ml}$ of triethylamine $(22 \mathrm{mmol})$ and $244 \mathrm{mg}$ of 4-dimethylaminopyridine ( $2 \mathrm{mmol}$ ) in $40 \mathrm{ml}$ of dioxane was added a solution of di-tert-butyldicarbonate $(4.58 \mathrm{~g}, 21 \mathrm{mmol})$ in $15 \mathrm{ml}$ of dioxane. After two hours, the reaction mixture was poured into $100 \mathrm{ml}$ of ice cold water and stirred for 15 minutes. The precipitate was then filtered, washed with water and dissolved in $\mathrm{CHCl}_{3}$. The organic phase was dried over $\mathrm{Na}_{2} \mathrm{SO}_{4}$ and concentrated to a small volume. Compound 7 ( $4 \mathrm{~g}, 16.19 \mathrm{mmol}$, yield $80.9 \%$ ) was obtained as white crystals by addition of $n$-hexane: TLC (silica gel) $\mathrm{Rf}=0.42(n$-hexane - acetone $7: 3) ; \mathrm{mp} 97.4^{\circ} \mathrm{C}$; ${ }^{1} \mathrm{H} \mathrm{NMR}\left(\mathrm{CDCl}_{3}\right) \delta 7.95(2 \mathrm{H}, \mathrm{m}), 7.80(2 \mathrm{H}, \mathrm{m}), 1.63$ (9H, s); IR (Nujol) $\mathrm{cm}^{-1} 1802,1776,1720$; FAB-MS $m / z$ $248\left(\mathrm{MH}^{+}, 100 \%\right)$.

Anal Calcd for $\mathrm{C}_{13} \mathrm{H}_{13} \mathrm{NO}_{4}$ : C 63.15, H 5.26, N 5.66. Found:

C 62.19, H 5.32 , N 5.57 (about $1.5 \%$ of phtalimide cocrystallizes with 7$)^{19)}$

1- $N$-Desmethyl-25- $N$-phthaloylgoldinamine (8)

To a solution of 4 formic acid salt $(546 \mathrm{mg}, 1 \mathrm{mmol})$ in $5 \mathrm{ml}$ of DMF, triethylamine $(0.35 \mathrm{ml}, 2.5 \mathrm{mmol})$ and $N$-tert-butoxycarbonylphthalimide (7) $(247 \mathrm{mg}, 1 \mathrm{mmol})$ were added at $0^{\circ} \mathrm{C}$. After stirring at room temperature for 2 hours, the reaction mixture was treated with $30 \mathrm{ml}$ of ice cold water and then with $3 \mathrm{ml}$ of $1 \mathrm{~N} \mathrm{HCl}$. The yellow precipitate was filtered, washed with water $(3 \times$ $20 \mathrm{ml})$ and $\mathrm{Et}_{2} \mathrm{O}(3 \times 20 \mathrm{ml})$. The crude solid material was purified by flash chromatography $\left(\mathrm{CHCl}_{3}-\mathrm{MeOH} 95: 5\right.$; $\left.\mathrm{CHCl}_{3}-\mathrm{MeOH} 92: 8\right)$ to give $350 \mathrm{mg}$ of $8(0.55 \mathrm{mmol})$ as a yellow solid. An analytical sample was obtained by reversed phase chromatography (water-acetonitrile from 70:30 to 65:35): Rt (HPLC) 20.3/21.1 minutes, gradient profile as for compound 4 ; IR (Nujol) $\mathrm{cm}^{-1}$ $1770,1713,1610 ;{ }^{1} \mathrm{H}$ NMR (DMSO- $\left.d_{6}\right) \delta 11.4$ (1H, br s), 11.1 (1H, brs), $7.85(4 \mathrm{H}, \mathrm{m}), 7.27(1 \mathrm{H}, \mathrm{d} 7.1 \mathrm{~Hz}), 6.83$ $(1 \mathrm{H}, \mathrm{d} 9.3 \mathrm{~Hz}), 6.61(2 \mathrm{H}, \mathrm{m}), 6.48(1 \mathrm{H}, \mathrm{dd} 11.0,14.5 \mathrm{~Hz})$, $6.34(1 \mathrm{H}, \mathrm{m}), 5.97(2 \mathrm{H}, \mathrm{m}), 5.91(1 \mathrm{H}, \mathrm{d} 7.2 \mathrm{~Hz}), 5.72$ $(1 \mathrm{H}, \mathrm{m}), 4.48(2 \mathrm{H}, \mathrm{m}), 4.26(2 \mathrm{H}, \mathrm{d} 5.8 \mathrm{~Hz}), 4.13(2 \mathrm{H}, \mathrm{m})$, $4.04(1 \mathrm{H}, \mathrm{m}), 3.05(3 \mathrm{H}, \mathrm{s}), 2.05(1 \mathrm{H}, \mathrm{m}), 1.86(3 \mathrm{H}, \mathrm{s}), 1.58$ $(3 \mathrm{H}, \mathrm{s}), 0.73(3 \mathrm{H}, \mathrm{d} 6.8 \mathrm{~Hz}) ;[\alpha]_{\mathrm{D}}^{25}-42.4^{\circ}(c 0.85, \mathrm{MeOH})$; ESI-MS $m / z 631\left(\mathrm{MH}^{+}, 100 \%\right), 599(30 \%), 449$ (15\%).

Anal Calcd for $\mathrm{C}_{35} \mathrm{H}_{38} \mathrm{~N}_{2} \mathrm{O}_{9}$ : C 66.65, H 6.07, N 4.44 . Found:

C 66.12, H 5.95, N 4.39 .

3-Methoxy-2,4-dimethyl-8-( $N^{\prime}$-phenylureido)-4E,6Eoctadienal (9)

A solution of sodium metaperiodate $(5.1 \mathrm{~g}, 24 \mathrm{mmol})$ in $75 \mathrm{ml}$ of water was added dropwise to a well stirred solution of $6(2.5 \mathrm{~g}, 4 \mathrm{mmol})$ and ammonium acetate $(462 \mathrm{mg}, 6 \mathrm{mmol})$ in a mixture of $50 \mathrm{ml}$ of dioxane and $15 \mathrm{ml}$ of $\mathrm{MeOH}$. A transient wine-red color developed immediately indicating the liberation of iodine. The 
mixture was stirred overnight, the precipitate was filtered off and washed with dioxane. The solution was diluted with water $(100 \mathrm{ml})$ and extracted with $\mathrm{Et}_{2} \mathrm{O}(5 \times 50 \mathrm{ml})$. The organic phase was washed with $0.1 \mathrm{~N} \mathrm{NaOH}(100 \mathrm{ml})$, $100 \mathrm{ml}$ of brine, dried over $\mathrm{Na}_{2} \mathrm{SO}_{4}$ and evaporated in vacuo giving $760 \mathrm{mg}$ of $9(2.4 \mathrm{mmol})$ as a straw colored syrup. This material showed a single spot in TLC (silica gel) with $\mathrm{Rf}=0.3$ ( $n$-hexane - acetone $6: 4$ ) and was used without further purification; Rt (HPLC) 18.0 minutes, gradient profile as for compound $4 ;{ }^{1} \mathrm{H} \mathrm{NMR}\left(\mathrm{CDCl}_{3}\right)$ $\delta 9.7(1 \mathrm{H}, \mathrm{d} 3.1 \mathrm{~Hz}), 7.4(4 \mathrm{H}, \mathrm{m}), 7.0(1 \mathrm{H}, \mathrm{t} 7.2 \mathrm{~Hz}), 6.38$ $(1 \mathrm{H}, \mathrm{dd} 10.9,15.2 \mathrm{~Hz}), 5.97(1 \mathrm{H}, \mathrm{d} 10.8 \mathrm{~Hz}), 5.67(2 \mathrm{H}$, m), $3.88(2 \mathrm{H}, \mathrm{m}), 3.59(1 \mathrm{H}, \mathrm{d} 9.5 \mathrm{~Hz}), 3.14(3 \mathrm{H}, \mathrm{s}), 2.55$ $(1 \mathrm{H}, \mathrm{m}), 1.63(3 \mathrm{H}, \mathrm{s}), 0.85(3 \mathrm{H}, \mathrm{d} 7.6 \mathrm{~Hz})$.

3-Methoxy-2,4-dimethyl-8-( $N^{\prime}$-phthalimido) $-4 E, 6 E-$ octadienal (10)

To a solution of compound $8(3.0 \mathrm{~g}, 4.95 \mathrm{mmol})$ and ammonium acetate $(14.85 \mathrm{mmol} ; 1.14 \mathrm{~g})$ in $100 \mathrm{ml}$ of dioxane - methanol $(3: 1 \mathrm{v} / \mathrm{v})$, was added dropwise over about 20 minutes, a solution of sodium metaperiodate $(29.7 \mathrm{mmol} ; 6.32 \mathrm{~g})$ in $100 \mathrm{ml}$ of water. A transient red-wine color developed immediately. After stirring for 5 hours, the resulting orange suspension was filtered and the precipitate washed with a small amount of dioxane. The solution was concentrated under vacuum, diluted with $200 \mathrm{ml}$ of water and extracted with $\mathrm{Et}_{2} \mathrm{O}(5 \times 70 \mathrm{ml})$. The organic phase was then washed with $100 \mathrm{ml}$ of $0.1 \mathrm{~N}$ $\mathrm{NaOH}$, water $(2 \times 100 \mathrm{ml})$, dried over $\mathrm{Na}_{2} \mathrm{SO}_{4}$ and evaporated yielding $700 \mathrm{mg}$ of compound 10 (2.1 mmol; yield $49 \%$ ) as a straw colored syrup that was used without further purification; TLC (silica gel) $\mathrm{Rf}=0.45$ ( $n$-hexane acetone $6: 4)$; Rt (HPLC): 10.2 minutes gradient profile: time (minute) 0 (B 40\%), 1 (B 40\%), 15 (B 75\%); ${ }^{1} \mathrm{H}$ NMR $\left(\mathrm{CDCl}_{3}\right) \delta 9.7(1 \mathrm{H}, \mathrm{d} 2.9 \mathrm{~Hz}), 7.85(2 \mathrm{H}, \mathrm{m}), 7.35$ $(2 \mathrm{H}, \mathrm{m}), 6.5(1 \mathrm{H}, \mathrm{dd} 10.7,14.9 \mathrm{~Hz}), 6.0(1 \mathrm{H}, \mathrm{d} 10.7 \mathrm{~Hz})$, $5.8(1 \mathrm{H}, \mathrm{m}), 4.36(2 \mathrm{H}, \mathrm{m}), 3.60(1 \mathrm{H}, \mathrm{d} 9.6 \mathrm{~Hz}), 3.15(3 \mathrm{H}$, s), $2.55(1 \mathrm{H}, \mathrm{m}), 1.68(3 \mathrm{H}, \mathrm{s}), 0.86(3 \mathrm{H}, \mathrm{d} 7.3 \mathrm{~Hz})$.

\section{2,4-Dinitrophenylhydrazone (11)}

Compound $9(38.3 \mathrm{mg}, 0.12 \mathrm{mmol})$ and 2,4 -dinitrophenylhydrazine $(24 \mathrm{mg}, 0.121 \mathrm{mmol})$ were stirred at room temperature for 72 hours. After filtration, the solvent was evaporated and the resulting crude solid material crystallized from EtOAc-hexane to give $18 \mathrm{mg}$ of compound $\mathbf{1 1}$ as an yellow-orange solid; Rt (HPLC) 27.1 minutes, gradient profile as for compound 4 ; $\mathrm{mp}$ $158 \sim 160^{\circ} \mathrm{C} ;{ }^{1} \mathrm{H} \mathrm{NMR}\left(\mathrm{CDCl}_{3}\right) \delta 11.0(1 \mathrm{H}, \mathrm{s}), 9.13(1 \mathrm{H}$, d $2.3 \mathrm{~Hz}), 8.31(1 \mathrm{H}$, dd $2.4,9.5 \mathrm{~Hz}), 7.94(1 \mathrm{H}, \mathrm{d} 9.6 \mathrm{~Hz})$, $7.61(1 \mathrm{H}, \mathrm{d} 5.6 \mathrm{~Hz}), 7.35(4 \mathrm{H}, \mathrm{m}), 7.15(1 \mathrm{H}, \mathrm{m}), 6.47$ $(1 \mathrm{H}, \mathrm{dd} 10.9,15.2 \mathrm{~Hz}), 6.30(1 \mathrm{H}, \mathrm{s}), 6.05(1 \mathrm{H}, \mathrm{d} 10.8 \mathrm{~Hz})$, $5.78(1 \mathrm{H}, \mathrm{m}), 4.81(1 \mathrm{H}, \mathrm{t} 5.7 \mathrm{~Hz}), 3.99(2 \mathrm{H}, \mathrm{m}), 3.44(1 \mathrm{H}$, d $9.0 \mathrm{~Hz}), 3.19(3 \mathrm{H}, \mathrm{s}), 2.77(1 \mathrm{H}, \mathrm{m}), 1.78(3 \mathrm{H}, \mathrm{s}), 1.06$ $(3 \mathrm{H}, \mathrm{d} 7.0 \mathrm{~Hz})$; ESI-MS $m / z 497\left(\mathrm{MH}^{+}, 100 \%\right), 465$ $(60 \%), 259(35 \%)$.

Anal Calcd for $\mathrm{C}_{24} \mathrm{H}_{28} \mathrm{~N}_{6} \mathrm{O}_{6}$ : C 58.05, H 5.68, N 16.92 . Found:
2,4-Dinitrophenylhydrazone (12)

Compound $10(35 \mathrm{mg}, 0.10 \mathrm{mmol})$ and 2,4-dinitrophenylhydrazine $(21.9 \mathrm{mg}, 0.11 \mathrm{mmol})$ were stirred at room temperature for 3 hours in $2 \mathrm{ml}$ of abs. EtOH. The solid was filtered, washed with abs. $\mathrm{EtOH}$ and crystalized from abs. EtOH to give $20 \mathrm{mg}$ of pure 12 as a yelloworange solid; Rt (HPLC) 30.5 minutes, gradient profile as for compound $4 ; \mathrm{mp} 157.5^{\circ} \mathrm{C} ;[\alpha]_{\mathrm{D}}^{25}+38.8^{\circ}(c 0.1$, $\left.\mathrm{CHCl}_{3}\right) ;{ }^{1} \mathrm{H} \mathrm{NMR}\left(\mathrm{CDCl}_{3}\right) \delta 11.0(1 \mathrm{H}, \mathrm{s}), 9.13(1 \mathrm{H}, \mathrm{d}$ $2.5 \mathrm{~Hz}), 8.31(1 \mathrm{H}$, dd $2.5,9.6 \mathrm{~Hz}), 7.94(1 \mathrm{H}, \mathrm{d} 9.6 \mathrm{~Hz})$, $7.88(2 \mathrm{H}, \mathrm{m}), 7.75(2 \mathrm{H}, \mathrm{m}), 7.60(1 \mathrm{H}, \mathrm{d} 5.7 \mathrm{~Hz}), 6.57$ $(1 \mathrm{H}, \mathrm{dd} 10.9,15.1 \mathrm{~Hz}), 6.02(1 \mathrm{H}, \mathrm{d} 10.7 \mathrm{~Hz}), 5.80(1 \mathrm{H}$, m), $4.39(2 \mathrm{H}, \mathrm{d} 6.4 \mathrm{~Hz}), 3.43(1 \mathrm{H}, \mathrm{d} 8.9 \mathrm{~Hz}), 3.18(3 \mathrm{H}$, s), $2.77(1 \mathrm{H}, \mathrm{m}), 1.57(3 \mathrm{H}, \mathrm{s}), 1.05(3 \mathrm{H}, \mathrm{d} 6.9 \mathrm{~Hz})$; FABMS $m / z 507\left(\mathrm{M}^{+}, 11 \%\right), 506(23.5 \%), 476(26.5 \%), 460$ $(88 \%) ; 429(23.5 \%), 401(35.2 \%), 327(100 \%)$.

Anal Calcd for $\mathrm{C}_{25} \mathrm{H}_{25} \mathrm{~N}_{5} \mathrm{O}_{7}$ : C 59.16, H 4.96, N 13.8 . Found:

C $59.52, \mathrm{H} 4.81, \mathrm{~N} 13.23$.

3-Methoxy-2,4-dimethyl-8- $N$-phenylureido- $2 E, 4 E$ octadienol (13)

Sodium borohydride $(22.7 \mathrm{mg} ; 0.6 \mathrm{mmol})$ was added to a solution of compound $9(190 \mathrm{mg} ; 0.60 \mathrm{mmol})$ in $3 \mathrm{ml}$ of abs. EtOH at $0^{\circ} \mathrm{C}$. After 45 minutes, the reaction was quenched with acetone (few drops), diluted with water $(20 \mathrm{ml})$, the $\mathrm{pH}$ was corrected to $2(1 \mathrm{~N} \mathrm{HCl})$ and extracted with $\mathrm{Et}_{2} \mathrm{O}(2 \times 20 \mathrm{ml})$. The organic phase was dried over $\mathrm{Na}_{2} \mathrm{SO}_{4}$ and evaporated to give a crude material that was purified on silica gel ( $n$-hexane-acetone $6: 4)$. The desired compound 13 (140 mg; $0.44 \mathrm{mmol}$; yield $73 \%$ ) was obtained as a glassy syrup: IR $\left(\mathrm{CDCl}_{3}\right) \mathrm{cm}^{-1} 3626$, 2964, 2934, 1674, 1526, 1499; ${ }^{1} \mathrm{H}$ NMR $\left(\mathrm{CDCl}_{3}\right) \delta 7.3$ $(4 \mathrm{H}, \mathrm{m}), 7.13(1 \mathrm{H}, \mathrm{m}), 6.43(1 \mathrm{H}, \mathrm{dd} 10.8,15.1 \mathrm{~Hz}), 6.40$ $(1 \mathrm{H}$, br s $), 5.96(1 \mathrm{H}, \mathrm{d} 10.7 \mathrm{~Hz}), 5.72(1 \mathrm{H}, \mathrm{m}), 4.86(1 \mathrm{H}$, m), $3.97(2 \mathrm{H}, \mathrm{m}), 3.61(2 \mathrm{H}, \mathrm{m}), 3.36(1 \mathrm{H}, \mathrm{d} 6.8 \mathrm{~Hz}), 3.30$ (1H, br s), $3.15(3 \mathrm{H}, \mathrm{s}), 1.90(1 \mathrm{H}, \mathrm{m}), 1.65(3 \mathrm{H}, \mathrm{s}), 0.68$ $(3 \mathrm{H}$, d $7.0 \mathrm{~Hz})$; FAB-MS $m / z 319\left(\mathrm{MH}^{+}, 40 \%\right), 287$ $(100 \%), 257(30 \%)$.

$$
\begin{array}{ll}
\text { Anal Calcd for } \mathrm{C}_{18} \mathrm{H}_{26} \mathrm{~N}_{2} \mathrm{O}_{3}: & \mathrm{C} 67.92, \mathrm{H} 8.17, \mathrm{~N} 8.80 . \\
\text { Found: } & \text { C 67.5, H 8.02, N 8.56. }
\end{array}
$$

$N$-(3-Methoxy-2,4-dimethyl-8- $N$-phenylureido$4 E, \overline{6} E$-octadienylidene)-4-methyl-1-piperazinamine (14)

4-Methyl-1-aminopiperazine $(86 \mathrm{mg} ; 0.75 \mathrm{mmol})$ in $1 \mathrm{ml}$ of THF were added to a solution of compound 9 ( $240 \mathrm{mg} ; 0.75 \mathrm{mmol}$ ) in $3 \mathrm{ml}$ of THF. After 3 hours at room temperature, the solvent was evaporated and the crude material purified by flash chromatography $\left(\mathrm{CHCl}_{3}-\mathrm{MeOH}\right.$ from $98: 2$ to $\left.95: 5\right)$ to give $185 \mathrm{mg}$ $(0.44 \mathrm{mmol}$; yield $59 \%)$ of a pure compound 14 as an orange-yellow syrup: Rt (HPLC) 14.1 minutes, gradient profile as for compound 4; IR $\left(\mathrm{CDCl}_{3}\right) \mathrm{cm}^{-1} 2974,2943$, $2885,2808,1674,1599,1528,1499 ;{ }^{1} \mathrm{H}$ NMR $\left(\mathrm{CDCl}_{3}\right)$ $\delta 7.31(4 \mathrm{H}, \mathrm{m}), 7.0(1 \mathrm{H}, \mathrm{m}), 6.93(1 \mathrm{H}, \mathrm{d} 6.3 \mathrm{~Hz}), 6.76$ $(1 \mathrm{H}$, brs $), 6.42(1 \mathrm{H}, \mathrm{dd} 10.3,15.2 \mathrm{~Hz}), 5.96(1 \mathrm{H}, \mathrm{d} 10.7$ $\mathrm{Hz}), 5.70(1 \mathrm{H}, \mathrm{m}), 5.16(1 \mathrm{H}, \mathrm{m}), 3.93(2 \mathrm{H}, \mathrm{m}), 3.37(1 \mathrm{H}$, d $8 \mathrm{~Hz}), 3.15(3 \mathrm{H}, \mathrm{s}), 3.01(4 \mathrm{H}, \mathrm{m}), 2.56(6 \mathrm{H}, \mathrm{m}), 2.31$ $(3 \mathrm{H}, \mathrm{s}), 1.65(3 \mathrm{H}, \mathrm{s}), 0.95(3 \mathrm{H}, \mathrm{d} 6.9 \mathrm{~Hz})$; FAB-MS $\mathrm{m} / \mathrm{z}$ 
$414\left(\mathrm{MH}^{+}, 100 \%\right)$.

Anal Calcd for $\mathrm{C}_{23} \mathrm{H}_{35} \mathrm{~N}_{5} \mathrm{O}_{2}$ : C 66.82, H 8.47, N 16.94 . Found:

C 66.25, H 8.25, N 16.34 .

5-Methoxy-4,6-dimethyl-10-( $N^{\prime}$-phenylureido $)$ $2 E, 6 E, 8 E$-decatrienoic Acid Ethyl Ester (15)

Triethyl phosphonoacetate $(536 \mathrm{mg} ; 2.39 \mathrm{mmol})$ was added to a suspension of sodium hydride $(60 \%$ oil dispersion; $83.6 \mathrm{mg} ; 2.09 \mathrm{mmol}$ ) in $5 \mathrm{ml}$ of dry THF under argon at $0^{\circ} \mathrm{C}$. After 20 minutes the pale yellow solution was cooled to $-50^{\circ} \mathrm{C}$ and a solution of compound 9 $(630 \mathrm{mg} ; 1.99 \mathrm{mmol})$ in $8 \mathrm{ml}$ of dry THF was added. The reaction was left stirring for 2 hours at $-10^{\circ} \mathrm{C}$, diluted with $\mathrm{Et}_{2} \mathrm{O}(15 \mathrm{ml})$, washed with water and the aqueous phase extracted with $\mathrm{Et}_{2} \mathrm{O}(2 \times 10 \mathrm{ml})$. The organic phase was washed with a saturated solution of $\mathrm{NaCl}$, dried over $\mathrm{Na}_{2} \mathrm{SO}_{4}$ and evaporated. Purification by flash chromatography ( $n$-hexane - acetone 7:3) gave $480 \mathrm{mg}$ of compound $15(1.51 \mathrm{mmol}$, yield $75 \%)$ as a syrup: TLC (silica gel) $\mathrm{Rf}=0.32$ ( $n$-hexane - ethyl acetate $8: 2) ; \mathrm{Rt}$ (HPLC) 23.7 minutes, gradient profile as for compound 4; IR $\left(\mathrm{CDCl}_{3}\right) \mathrm{cm}^{-1} 3434,2981,2934,1700,1684,1653,1524$; ${ }^{1} \mathrm{H}$ NMR $\left(\mathrm{CDCl}_{3}\right) \delta 7.31(4 \mathrm{H}, \mathrm{m}), 7.15(1 \mathrm{H}, \mathrm{m}), 7.02$ $(1 \mathrm{H}, \mathrm{dd} 7.4,15.8 \mathrm{~Hz}), 6.59(1 \mathrm{H}$, br s) $6.45(1 \mathrm{H}, \mathrm{dd} 10.7$, $15.0 \mathrm{~Hz}), 5.96(1 \mathrm{H}, \mathrm{d} 10.7 \mathrm{~Hz}), 5.84(1 \mathrm{H}, \mathrm{d} 15.8 \mathrm{~Hz}), 5.72$ $(1 \mathrm{H}, \mathrm{m}), 4.99(1 \mathrm{H}, \mathrm{t} 5.4 \mathrm{~Hz}), 4.19(2 \mathrm{H}, \mathrm{q} 7 \mathrm{~Hz}), 3.95(2 \mathrm{H}$, $\mathrm{m}), 3.26(1 \mathrm{H}, \mathrm{d} 8.6 \mathrm{~Hz}), 3.14(3 \mathrm{H}, \mathrm{s}), 2.52(1 \mathrm{H}, \mathrm{m}), 1.66$ $(3 \mathrm{H}, \mathrm{s}), 1.29(3 \mathrm{H}, \mathrm{t} 7 \mathrm{~Hz}), 0.90(3 \mathrm{H}, \mathrm{d} 6.9 \mathrm{~Hz}) ;[\alpha]_{\mathrm{D}}^{25}$ $+28.13^{\circ}$ (c $\left.0.16, \mathrm{CDCl}_{3}\right)$; FAB-MS $m / z 387\left(\mathrm{MH}^{+}\right.$, $100 \%), 355(30 \%), 259(55 \%)$.

Anal Calcd for $\mathrm{C}_{22} \mathrm{H}_{30} \mathrm{~N}_{2} \mathrm{O}_{5}$ : C 65.65, H 7.51, N 6.96. Found:

C 65.15, H 7.41, N 6.78 .

5-Methoxy-4,6-dimethyl-10-( $N^{\prime}$-phenylureido)$2 E, 6 E, 8 E$-decatrienoic Acid (16)

Compound $15(414 \mathrm{mg} ; 1.07 \mathrm{mmol})$ in $5 \mathrm{ml}$ of dioxane and $2.5 \mathrm{ml}$ of $1 \mathrm{~N} \mathrm{NaOH}$ were reacted at room temperature for 23 hours. The reaction was cooled to $0^{\circ} \mathrm{C}$, brought to $\mathrm{pH} 2$ with $1 \mathrm{~N} \mathrm{HCl}$, diluted with water and extracted with $\mathrm{CH}_{2} \mathrm{Cl}_{2}$. The organic phase was washed with saturated solution of $\mathrm{NaCl}$, dried over $\mathrm{Na}_{2} \mathrm{SO}_{4}$ and evaporated to give $353 \mathrm{mg}$ of compound $16(0.98 \mathrm{mmol}$; yield $91 \%$ ) as a pale yellow solid; Rt (HPLC) 12.7 minutes, gradient profile as for compound 4; IR (Nujol) $\mathrm{cm}^{-1} 3330,1693,1650,1597,1552 ;{ }^{1} \mathrm{H}$ NMR $\left(\mathrm{CDCl}_{3}\right)$ $\delta 7.29(4 \mathrm{H}, \mathrm{m}), 7.12(2 \mathrm{H}, \mathrm{m}), 6.98(1 \mathrm{H}, \mathrm{br} \mathrm{s}), 6.42(1 \mathrm{H}, \mathrm{dd}$ $10.8,14.9 \mathrm{~Hz}), 5.96(1 \mathrm{H}, \mathrm{d} 10.8 \mathrm{~Hz}), 5.84(1 \mathrm{H}, \mathrm{d} 15.6 \mathrm{~Hz})$, $5.70(1 \mathrm{H}, \mathrm{m}), 4.95(1 \mathrm{H}, \mathrm{m}), 3.95(2 \mathrm{H}, \mathrm{m}), 3.28(1 \mathrm{H}, \mathrm{d}$ $8.4 \mathrm{~Hz}), 3.15(3 \mathrm{H}, \mathrm{s}), 2.54(1 \mathrm{H}, \mathrm{m}), 1.66(3 \mathrm{H}, \mathrm{s}), 0.92$ $(3 \mathrm{H}, \mathrm{d} 6.9 \mathrm{~Hz})$; FAB-MS $m / z 359\left(\mathrm{MH}^{+}, 100 \%\right), 327$ $(50 \%)$.

$\begin{array}{ll}\text { Anal Calcd for } \mathrm{C}_{20} \mathrm{H}_{26} \mathrm{~N}_{2} \mathrm{O}_{4}: & \mathrm{C} 67.03, \mathrm{H} 7.26, \mathrm{~N} 7.82 . \\ \text { Found: } & \text { C 66.48, H 7.06, N 7.55. }\end{array}$

5-Methoxy-4,6-dimethyl-10-( $N^{\prime}$-phthalimido $)$ $2 E, 6 E, 8 E$-decatrienoic Acid Ethyl Ester (17)

To a suspension of sodium hydride $(60 \%$ oil dispersion; $30.8 \mathrm{mg} ; 0.77 \mathrm{mmol}$ ) in $2 \mathrm{ml}$ of dry THF under argon, triethyl phosphonacetate $(0.168 \mathrm{ml} ; 0.84 \mathrm{mmol})$ was added at $0^{\circ} \mathrm{C}$. After 30 minutes the pale yellow solution was cooled to $-50^{\circ} \mathrm{C}$ and compound 10 (230 $\mathrm{mg} ; 0.7 \mathrm{mmol}$ ) in $3 \mathrm{ml}$ of dry THF was added. The reaction was stirred for 2 hours at $-10^{\circ} \mathrm{C}$, diluted with $\mathrm{Et}_{2} \mathrm{O}$ $(10 \mathrm{ml})$ and washed with water. The acqueous phase was extracted with $\mathrm{Et}_{2} \mathrm{O}(2 \times 10 \mathrm{ml})$, the combined organic phases were washed with a saturated solution of $\mathrm{NaCl}$, dried over $\mathrm{Na}_{2} \mathrm{SO}_{4}$ and evaporated. The crude was purified by flash chromatography on silica gel ( $n$-hexane ethyl acetate $8: 2$ ) to give $230 \mathrm{mg}$ of compound $\mathbf{1 7}$ $(0.57 \mathrm{mmol}$; yield $82.7 \%)$ as a syrup; $\mathrm{Rf}=0.28(n-$ hexane - ethyl acetate $8: 2$ ); Rt (HPLC): 15.0 minutes gradient profile: time (minute) 0 (B 40\%), 1 (B 40\%), 15 (B 75\%), 20 (B 40\%); IR (Neat) $\mathrm{cm}^{-1}$ 2979, 2931, 2821, $1772,1713,1652 ;{ }^{1} \mathrm{H}$ NMR $\left(\mathrm{CDCl}_{3}\right) \delta 7.87(2 \mathrm{H}, \mathrm{m}), 7.72$ $(2 \mathrm{H}, \mathrm{m}), 7.0(1 \mathrm{H}, \mathrm{dd} 7.56,15.6 \mathrm{~Hz}), 6.54(1 \mathrm{H}, \mathrm{dd} 10.8$, $15.1 \mathrm{~Hz}), 5.94(1 \mathrm{H}, \mathrm{d} 10.9 \mathrm{~Hz}), 5.82(1 \mathrm{H}, \mathrm{d} 16 \mathrm{~Hz}), 5.75$ $(1 \mathrm{H}, \mathrm{m}), 4.36(2 \mathrm{H}, \mathrm{d} 6.6 \mathrm{~Hz}), 4.18(2 \mathrm{H}, \mathrm{q} 7.1 \mathrm{~Hz}), 3.23$ $(1 \mathrm{H}, \mathrm{d} 8.8 \mathrm{~Hz}), 3.1(3 \mathrm{H}, \mathrm{s}), 2.49(1 \mathrm{H}, \mathrm{m}), 1.67(3 \mathrm{H}, \mathrm{s})$, $1.28(3 \mathrm{H}, \mathrm{t} 7.3 \mathrm{~Hz}), 0.87(3 \mathrm{H}, \mathrm{d} 6.9 \mathrm{~Hz}) ;[\alpha]_{\mathrm{D}}^{25}+32.06^{\circ}$ (c $\left.0.97, \mathrm{CHCl}_{3}\right)$; ESI-MS $398\left(\mathrm{MH}^{+}, 30 \%\right), 366(25 \%)$, $320(100 \%), 292(15 \%), 173(60 \%)$.

Anal Calcd for $\mathrm{C}_{23} \mathrm{H}_{27} \mathrm{NO}_{5}$ : C 69.5, $\mathrm{H} 6.84, \mathrm{~N} 3.52$. Found:

C 68.86, H 6.77, N 3.43 .

Bacterial Protein Synthesis Cell Free System

$\mathrm{L}-\left[{ }^{14} \mathrm{C}\right]$ Phenylalanine $(513 \mathrm{mCi} / \mathrm{mmol})$ was from the Radiochemical Centre, Amersham, Bucks., UK. Poly $(U)$ was from Boeringer Mannheim, Germany. Nucleotides and all other reagents were from Sigma Chemical Company, St. Louis, MO, U.S.A. Crude extracts were prepared from E. coli and the polyphenylalanine synthesis was performed according to the literature ${ }^{20)}$. The compound was dissolved in DMSO $: \mathrm{H}_{2} \mathrm{O} 1: 9(\mathrm{v} / \mathrm{v})$ and $5 \mu \mathrm{l}$ of the mother-solution were stirred for 3 minutes with $65 \mu \mathrm{l}$ of S30 preparation in a microtiter well. $30 \mu \mathrm{l}$ of a mixture of t-RNA, poliU and L-phenylalanine ${ }^{3} \mathrm{H}$ were added and the mixture was incubated for 1 hour at room temperature. The reaction was then quenched by incubating at $30^{\circ} \mathrm{C}$ with $6 \mathrm{~N} \mathrm{NaOH}(50 \mu \mathrm{l} /$ well $)$ and then neutralized with $6 \mathrm{~N} \mathrm{HCl}(50 \mu \mathrm{l} /$ well). Finally, $20 \%$ trichloroacetic acid $(100 \mu \mathrm{l} /$ well $)$ was sequentially added and the mixture was maintained overnight at $4^{\circ} \mathrm{C}$. The precipitate was filtered and the radioactivity was measured.

\section{Measurement of In Vitro Antibacterial Activity}

The MICs determinations were performed by standard methods with strains taken from frozen stock cultures maintained at $-80^{\circ} \mathrm{C}$. Iso-Sensitest broth was used for all bacteria except Streptococci (Todd-Hewitt broth), $N$. gonorrhoeae (GC broth) and H. influenzae (brain heart infusion broth; Oxoid plus $1 \%$ supplement $\mathrm{C}$ ). All tests were incubated aerobically; $N$. gonorrhoeae and $H$. influenzae were incubated in a $5 \% \mathrm{CO}_{2}$ atmosphere. All tests were incubated at $35^{\circ} \mathrm{C}$. 
Digestion of EF-Tu, EF-Tu-kirromycin and EF-Tucompound 6 by Trypsin

EF-Tu-GDP $(50 \mu \mathrm{g})$ was incubated with $10 \mu \mathrm{g}$ of kirromycin or alternatively with $10 \mu \mathrm{g}$ of compound 6 for 1 hour at room temperature in buffer Tris $20 \mathrm{~mm}, \mathrm{MgCl}_{2}$ $10 \mathrm{~mm}$ and dithiotreitol $2.5 \mathrm{~mm}$ at $\mathrm{pH}$ 7.7. Proteolitic cleavage by trypsin of EF-Tu, EF-Tu/kirromycin and EF-Tu/compound 6 was performed as described ${ }^{21)}$. As depicted in Fig. 2 lines 2, 3 and 4 referred to aliquots removed after 2 minutes while lines 5, 6 and 7 after 30 minutes. In both cases the reaction was terminated by boiling for 5 minutes in the gel sample buffer. The protein was analyzed by SDS-PAGE on $20 \%$ acrilamide phast Gel with PHAST SYSTEM (Pharmacia).

\section{Acknowledgments}

We would like to thank Dr. E. Restelli for the supply of kirromycin, Dr. M. KURZ for recording the NMR spectra. Many thanks are also due to A. Guindani, A. Soffientini and F. Ripamonti for the biological experiments, and to Dr. C. Sottani, Dr. E. Taglietti and Dr. M. Nebuloni for the analytical support.

\section{References}

1) Wolf, H.; G. Chinali \& A. Parmeggiani: Mechanism of the inhibition of protein synthesis by kirromycin. Eur. J. Biochem. 75: 67 75, 1977

2) Parmeggiani, A. \& G. Sander: Mechanism of action of kirromycin-like antibiotics. Annu. Rev. Microbiol. 85: $557 \sim 577,1985$

3) Frost, B. M.; M. E. Valiant, B. Weissberger \& E. L. DULANEY: Antibacterial activity of efrotomycin. J. Antibiotics 29: 1083 1091, 1976

4) Frost, B. M.; M. E. Valiant \& E. L. Dulaney: Antibacterial activity of heneicomycin. J. Antibiotics 32: $626 \sim 629,1979$

5) Fisher, E; H. Wolf, K. Hantke \& A. Parmeggiani: Elongation factor $\mathrm{Tu}$ resistant to kirromycin in an Escherichia coli mutant altered in both tuf genes. Proc. Natl. Acad. Sci. 74: $4341 \sim 4345,1977$

6) Parmeggiani, A. \& G. Sander: Properties and action of kirromycin (mocimycin) and related antibiotics. In Topics in Antibiotic Chemistry. Vol. 5. Ed., P. G. SAmmes, pp. $159 \sim 221$, Ellis Horwood Ltd., Chirchester, 1980

7) Hall, C. C.; J. D. Watkins \& N. H. Georgopapadakou: Effects of elfamycins on EF-Tu from Escherichia coli and Sthaphylococcus aureus. Antimicrob. Agents Chemother. 33: $322 \sim 325,1989$
8) Maehr, H.; M. Leach, T. H. Williams \& J. F. Blount: The chemistry of aurodox and related antibiotics. Canadian J. Chem. 58: 501 526, 1980

9) Maehr, H.; M. Leach, L. YarmchuK \& M. Mitrovic: Chemical conversion of mocimycin to aurodox and derivatives of aurodox, goldinamine and mocimycin. $\mathbf{J}$. Antibiotics 32: $361 \sim 367,1979$

10) Chinal, G.: Synthetic analogs of aurodox and kirromycin active on elongation factor Tu from Escherichia coli. J. Antibiotics 34: 1039 1045, 1981

11) Chinal, G.: Identification of the part of kirromycin structure that acts on elongation factor Tu. FEBS Letters 131: $94 \sim 98,1981$

12) Barber, J.; J. A. Carver, R. Leberman \& G. M. V. TebB; The molecular basis of kirromycin (mocimycin) action. A ${ }^{1} \mathrm{H}$ NMR study using deutereted elongation factor $\mathrm{Tu}$. J. Antibiotics 61: 202 206, 1988

13) Beretta, G.; F. Le Monnier, E. Selva \& F. Marinelli: A novel producer of the antibiotic kirromycin belonging to the genus Actinoplanes. J. Antibiotics 46: $1175 \sim 1177$, 1993

14) Barber, J.; A. E. Derome, T. D. Howerd, L. Lian \& G. TEBB: Full assignement of the ${ }^{1} \mathrm{H}$ and ${ }^{13} \mathrm{C}$ NMR spectra of the antibiotic kirromycin (mocimycin). Magnetic Resonance in Chemistry 27: 748 753, 1989

15) Greene, T. W. \& P. G. M. Wuts: In Protective groups in organic synthesis (2nd edition). p. 358, Ed. John Wiley \& Sons, Inc., 1991

16) Hesse, G. \& K. Mix: Ungewöhnlich verlaufende oxydationen mit perjodsäure. Chem. Ber. 92: 2427 2434, 1959

17) Miele, A.; B. P. Goldstein, M. Bandera, C. Jarvis, A. RESCONI \& R. J. Williams: Differential susceptibilities of enterococcal species to elfamycin antibiotics. J. Clinical Microbiology 32: 2016 2018, 1994

18) Blumenthal, T; J. Douglass \& D. Smith: Conformational alteration of protein synthesis elongation factor EF-Tu by EF-Ts and kirromycin. Proc. Natl. Acad. Sci. U.S.A. 74: $3264 \sim 3267,1977$

19) Worster, P. M.; C. C. Leznoff \& C. R. MCArthur: $N$-(Ethoxycarbonyl)phthalimide. An improved procedure. J. Org. Chem. 45: 174 175, 1980

20) Landini, P.; M. Bandera, B. P. Goldstein, F. Ripamonti, A. Soffientini, K. Islam \& M. Denaro: Inhibition of bacterial protein synthesis by elongation factor Tu-binding antibiotics MDL 62,879 and efrotomycin. J. Biochem. 283: 649 652, 1992

21) JACOBSON, G. R. \& J. P. Rosenbush: Limited proteolysis of elogation factor Tu from Escherichia coli. Multiple intermediates. Eur. J. Biochem. 77: 409 417, 1977 